\title{
Pelatihan Pembuatan Nugget Ikan Tongkol Jakandor sebagai Bentuk Inovasi untuk Meningkatkan Perekonomian Masyarakat Desa Kuala Peudawa Puntong Kecamatan Idi Rayeuk Kabupaten Aceh Timur
}

\section{Muhammad Baihaki*1, Leni Novita Sari², Ayu Irawati Sidabutar ${ }^{3}$, Ega Al Ridha4, Nova Purnama Lisa ${ }^{5}$, Meilandy Purwandito ${ }^{6}$, Nina Fahriana ${ }^{7}$}

\author{
1,2,3,4,5,6,7Teknik Sipil, Fakultas Teknik, Universitas Samudra, Indonesia \\ *e-mail: tmbaihaki@gmail.com ${ }^{1}$, leninovitasari00@gmail.com ${ }^{2}$, ayu.sidabutar8008@gmail.com ${ }^{3}{ }_{\text {. }}$ \\ egaalridha01@gmail.com ${ }^{4}$,novapurnama@unsam.ac.id ${ }^{5}$, meilandy@unsam.ac.id ${ }^{6}$. \\ ninafahriana@unsam.ac.id ${ }^{7}$
}

\begin{abstract}
Abstrak
Ikan tongkol merupakan salah satu komoditas perikanan andalan dari perairan Indonesia yang menjadi primadona, serta memiliki kandungan gizi protein yang tinggi dan kaya akan asam lemak omega 3. Desa Kuala Peudawa Puntong ialah tempat tinggalnya para nelayan yang melaut setiap hari, mereka membawa pulang berbagai macam ikan, salah satunya ikan tongkol yang melimpah. Namun, pemanfaatan menjadi produk olahan kurang dilakukan secara optimal. Tujuan dari program kerja tersebut adalah melatih masyarakat dalam mengolah ikan tongkol menjadi nugget, bahkan dapat menjual produk nugget ikan tongkol sehingga dari penjualan tersebut dapat membantu perekenomian warga setempat, serta membantu meningkatkan kemampuan kewirausahaan di kalangan masyarakat yang mampu, handal, dan unggul. Pendekatan yang dilakukan untuk menawarkan solusi atas permasalahan yang dihadapi oleh masyarakat Desa Kuala Peudawa Puntong adalah memberikan pelatihan dan peningkatan pengetahuan dan penyusunan strategi pemasaran yang tepat dengan menggunakan ikan tongkol sebagai produk untuk berwirausaha. Penduduk desa juga sangat berantusias mengikuti sosialisasi ini dan mendapat respon positif atas kegiatan yang dilakukan. Berdasarkan hasil sosialisasi tersebut, diharapkan bagi masyarakat Desa Kuala Peudawa Puntong dapat mengolah ikan tongkol menjadi sebuah produk yang dapat dijual dengan nilai tinggi guna meningkatkan perekonomian desa setempat.
\end{abstract}

Kata kunci: Ikan Tongkol, Kecamatan Idi Rayeuk, Nugget, Produk

\begin{abstract}
Tuna fish is one of the mainstay fisheries commodities from Indonesian waters which is excellent, and has a high protein nutritional content and is rich in omega 3 fatty acids. Kuala Peudawa Puntong Village is the residence of fishermen who go to sea every day, they bring home various kinds of fish, one of which is abundant tuna. However, the utilization into processed products is not carried out optimally. The purpose of the work program is to train the community in processing tuna into nuggets, and even to sell tuna nuggets products so that from these sales they can help the local people's economy, and help improve entrepreneurial skills among people who are capable, reliable, and superior. The approach taken to offer solutions to the problems faced by the people of Kuala Peudawa Puntong Village is to provide training and increase knowledge and develop appropriate marketing strategies using tuna as a product for entrepreneurship. The villagers were also very enthusiastic about participating in this socialization and received a positive response to the activities carried out. Based on the results of the socialization, it is hoped that the people of Kuala Peudawa Puntong Village can process tuna into a product that can be sold with high value in order to improve the local village economy.
\end{abstract}

Keywords: Idi Rayeuk District, Nugget, Product, Tuna Fish

\section{PENDAHULUAN}

Desa Kuala Peudawa Puntong merupakan salah satu desa yang terletak di pesisir lautan yang berada di Kecamatan Idi Rayeuk, Kabupaten Aceh Timur, Provinsi Aceh. Desa ini mempunyai 4 dusun, yaitu Dusun Tengah, Dusun Barat, Dusun Selatan, dan Dusun Timur dengan jumlah penduduk 1.700 jiwa. Masyarakatnya kebanyakan berprofesi sebagai nelayan dan sebagian kecilnya sebagai petani. 
Ikan tongkol merupakan salah satu komoditas perikanan andalan dari perairan Indonesia yang menjadi primadona, serta memiliki kandungan gizi protein yang tinggi dan kaya akan asam lemak omega 3. Sejak dulu, masyarakat Indonesia terbiasa mengonsumsi ikan tongkol sebagai lauk pauk pendamping nasi. Ikan tongkol diminati oleh masyarakat Indonesia karena rasanya enak dan harganya juga relatif murah.

Desa Kuala Peudawa Puntong merupakan salah satu wilayah yang mempunyai hasil laut yang melimpah, khususnya ikan tongkol hasil dari nelayan setempat. Dikarenakan hasil ikan tongkol di Desa Kuala Peudawa Puntong yang sangat melimpah, dan kurangnya inovasi dalam mengolahnya menjadi sebuah produk. Maka dari itu, solusi dari permasalahan tersebut ialah melakukan sosialisasi dalam membuat nugget dengan bahan utama yaitu ikan tongkol.

Program pengabdian kepada masyarakat yang direalisasikan dalam bentuk kegiatan Kerja Kuliah Nyata Tematik (KKN-T) Universitas Samudra 2021 memiliki tujuan yang diharapkan dalam inovasi pengolahan ikan tongkol menjadi nugget dapat membantu meningkatkan pendapatan ekonomi masyarakat, serta menggali potensi yang bisa dikembangkan dalam pengolahan ikan tongkol. Hal ini dapat dimanfaatkan masyarakat Desa Kuala Peudawa Puntong sebagai roda penggerak ekonomi dengan membuat usaha nugget ikan tongkol. Adapun Pelatihan dan pemberdayaan diperuntukan bagi ibu-ibu rumah tangga agar dapat membantu memenuhi kebutuhan perekonomian keluarga. Mahasiswa berusaha mengajak warga masyarakat mengolah ikan tongkol menjadi nugget ikan tongkol agar menjadi olahan yang lebih variatif.

\section{METODE PELAKSANAAN}

Metode yang digunakan dalam kegiatan pengabdian adalah penyuluhan dan praktik. Pelaksanaan penyuluhan pembuatan nugget ikan tongkol dilaksanakan Rabu, 25 Agustus 2021 pukul 15.00 WIB sampai selesai di Mushola Desa Kuala Peudawa Puntong. Kegiatan dilakukan dengan metode memberikan penjelasan materi, tanya jawab, dan praktikum. Penyuluhan bekerjasama dengan pihak Pemuda Gampong Desa Kuala Peudawa Puntong yang diikuti oleh ibu-ibu rumah tangga. berikut:

Alat dan bahan yang digunakan untuk membuat nugget ikan tongkol antara lain sebagai

Tabel 1. Alat dan Bahan yang digunakan

\begin{tabular}{cc}
\hline Alat & Bahan \\
\hline Panci Kukus & 1 kg Daging Ikan Tongkol \\
Kompor & 250 gr Tepung Terigu \\
Gas LPG & 4 Buah Wortel \\
Loyang & Daun Bawang Secukupnya \\
Wajan & 3 Butir Telur \\
Piring & 1 Sdm Merica \\
Sendok & 1 Sdm Garam \\
Sarung Tangan Plastik & 2 Siung Bawang Putih \\
Serbet & Tepung Panir \\
Tissue & Penyedap Rasa \\
& Air \\
& Minyak \\
\hline
\end{tabular}

Langkah kerjanya adalah sebagai berikut.

1. Menyiapkan semua bahan-bahan yang akan digunakan.

2. Memotong wortel dan daun bawang kecil-kecil. Apabila ingin mengunakan sayuran lain bisa karena disesuaikan dengan selera.

3. Sebelum semua dicampurkan hancurkan ikan tongkol sampai halus dan campurkan semua bahan kecuali tepung panir. 
4. Setelah bahan tercampur rata langkah selanjutnya adalah menuangkan adonan ke loyang lalu mengukus adonan hingga matang kurang lebih 30 menit.

5. Setelah adonan matang, adonan siap untuk dipotong sesuai selera. Setelah memotong adonan, kemudian siapkan telur yang sudah dikocok sebagai bahan untuk perekat nugget ikan tongkol dengan tepung panir.

6. Setelah semua terbalur tepung panir langkah selanjutnya adalah digoreng untuk siap dikonsumsi.

7. Sedangkan untuk penyajian frozen food hanya sampai pembaluran tepung panir kemudian dikemas. Hal ini dapat digoreng sewaktu-waktu dibutuhkan selain itu juga dapat disimpan dalam jangka waktu cukup lama.

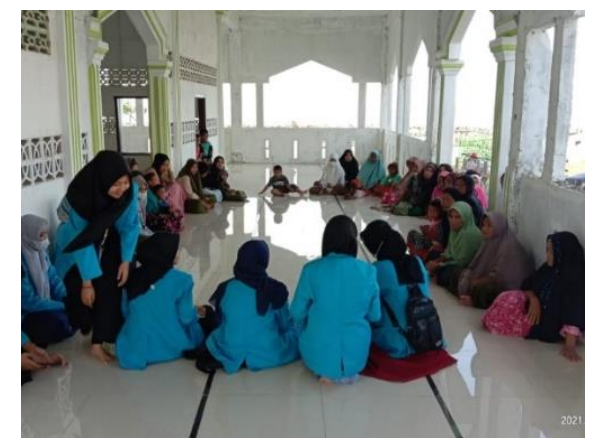

Gambar 1. Pelaksanaan kegiatan sosialisai yang sedang berlangsung (Pada kegiatan ini warga diminta untuk dapat hadir dalam pengarahan cara membuat nugget dari ikan tongkol)

\section{HASIL DAN PEMBAHASAN}

Pengabdian kepada masyarakat adalah usaha untuk menyebarluaskan ilmu pengetahuan, teknologi, dan seni kepada masyarakat. Kegiatan tersebut harus mampu memberikan suatu nilai tambah bagi masyarakat, baik dalam kegiatan ekonomi, kebijakan, dan perubahan perilaku (sosial).

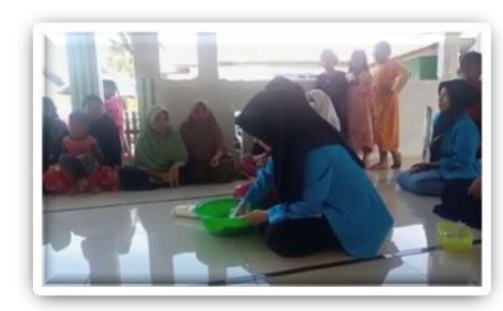

(a)



(b)

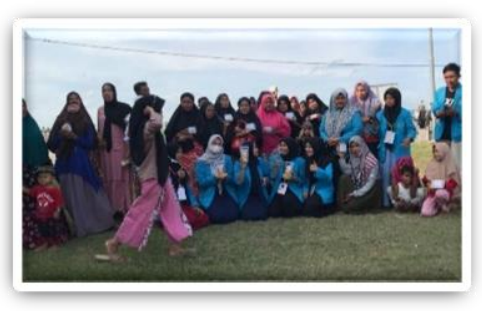

(c)

Gambar 2. (a) sosialisai cara membuat nugget (b) hasil nugget yang telah dikemas dan siap dipasarkan (c) foto bersama peserta sosialisasi nugget ikan tongkol

Respon dari peserta pelatihan pembuatan nugget ikan tongkol ini sangat responsif dan tertarik akan pembuatan serta inovasi yang dilakukan, karena belum pernah ada sebelumnya. Nugget yang dikenal masyarakat di desa ini adalah makanan mewah yang tidak bisa dikonsumsi oleh masyarakat sewaktu-waktu karena harganya mahal, nugget biasanya terbuat dari daging sapi atau ayam dengan kualitas yang bagus serta proses pembuatan yang higenis dalam pabrik yang besar sehingga harganya mahal. Namun nugget dengan bahan dasar menggunakan ikan tongkol dapat dijadikan olahan nugget seperti nugget yang lain, selain bahannya murah, mudah didapat serta dapat dijadikan inovasi dalam penjualan, kualitas juga tidak menjadi buruk namun dengan penambahan bahan-bahan lain seperti sayuran dapat menambah kandungan vitamin dan kandungan gizi yang lain. Sayuran yang dapat ditambahakan dapat sesuai selera seperti wortel, daun bawang, seledri, sawi, tomat, kubis atau yang lainnya. 
Manfaat lain yang didapatkan berupa daya simpan nugget yang lebih lama, karena nugget dapat disebut dengan frozen food yang dapat disimpan dalam lemari es dan dapat digunakan dalam jangka waktu yang cukup lama serta dapat dimasak kapan saja. Hal ini sangat menarik untuk diproduksi dalam jangka besar.

Proses distribusi dapat berupa olahan yang sudah digoreng maupun yang siap digoreng. Pengemasan produk ini menggunakan plastik klip zipper yang dapat diisi beberapa buah nugget. Produk nugget ikan tongkol ini juga diberikan label pada kemasan yang bernama Jakandor. Berikut produk dan kegiatan dilakukan di Desa Kuala Peudawa Puntong, Kecamatan Idi Rayeuk, Kabupaten Aceh Timur, Provinsi Aceh.

\section{KESIMPULAN}

Desa Kuala Peudawa Puntong merupakan desa pesisir laut yang ditinggali oleh nelayan setempat yang hasil lautnya berupa ikan, termasuk ikan tongkol. Pemanfaatan ikan tongkol menjadi nugget merupakan sebuah pencapaian inovatif akan hasil olahan daging ikan tongkol. Pelaksanaan Kuliah Kerja Nyata Tematik (KKN-T) Universitas Samudra 2021 ini bertujuan untuk untuk memberikan edukasi dan pelatihan guna meningkatkan perekonomian warga setempat agar desanya menjadi berkembang.

\section{UCAPAN TERIMA KASIH}

Ucapan terima kasih kepada Bpk. Karyani selaku kepala Desa Kuala Peudawa Puntong beserta seluruh masyarakat Desa Kuala Peudawa Puntong yang telah memberikan kesempatan dan telah berpartisipasi mengikuti sosialiasi yang telah dilakukan.

\section{DAFTAR PUSTAKA}

Abdullah, R., Puspitaningsih, A., Halu, U., Manajemen, P. S., Ekonomi, F., Buton, U. M., Author, C., Abdullah, R., Manajemen, P. S., Ekonomi, F., \& Buton, M. (n.d.). PELATIHAN PEMBUATAN NUGGET IKAN, GUNA MENINGKATKAN PENDAPATAN NELAYAN PESISIR. 2666, 297-298.

Hidayat, F., Nurman, S., Yulia, R., \& Ermaya, D. (2019). Pelatihan Pembuatan Nugget Dengan Penambahan Sayuran Di Panti Asuhan Yayasan Islam Media Kasih Banda Aceh. BAKTIMAS : Jurnal Pengabdian Pada Masyarakat, 1(3), 141. https://doi.org/10.32672/btm.v1i3.1425

Kasim, F., Tuli, M., \& Paramata, A. R. (2019). Inovasi Olahan Pangan Bagi Masyarakat Desa Omuto Kec Biau Kabupaten Gorontalo Utara. Jurnal Sibermas (Sinergi Pemberdayaan Masyarakat), 8(1), 32-42. https://doi.org/10.37905/sibermas.v8i1.7699

Kresnasari, D., Mustikasari, D., \& Kurniawati, A. (2019). Pembuatan Nugget Ikan (Fish Nugget) Sebagai Salah Satu Usaha Deferensiasi Pengolahan Ikan Di Sekolah Alam Banyu Belik. $\begin{array}{lllll}\text { Cendekia: } \quad \text { Jurnal } & \text { Pengabdian }\end{array}$ https://doi.org/10.32503/cendekia.v1i2.589

Pengabdian, J., Masyarakat, K., Nizar, R., Siswati, L., Ariyanto, A., Agribisnis, S., Pertanian, F., \& Kuning, U. L. (2021). Pemberdayaan Kelompok Arisan Ibu-Ibu Perumahan Lancang Kuning Melalui Pelatihan Pembuatan Nugget Jantung Pisang. 5(6), 1603-1610.

Pusat, B., Kab, S., Timur, A., Statistics, B. P. S., Aceh, O. F., \& Regency, T. (n.d.). Idi rayeuk.

Putra, I. K., \& Asrianty. (2019). Pemberdayaan Masyarakat Melalui Pengembangan Produk Olahan Ikan. Jurnal Pengabdian Pada Masyarakat, $1(1), 1$. http://promkes.kemkes.go.id/content/?p=1668

Ruhibnur, R., Ketapang, P., \& Ketapang, P. (2016). Nugget Dan Kerupuk Ikan Tongkol Sebagai Alternatif Usaha Untuk Meningkatkan Pendapatan Masyarakat. Agromix, 7(1). https://doi.org/10.35891/agx.v7i1.706

Sumiati, T. (2008). Terhadap Mutu Cerna Protein Ikan Mujair (Tilapia mossambica). In 2008. 
Wilayah, M., Benda, K., \& Selatan, T. (2021). Pelatihan Pembuatan Nugget Singkong Pada. 01, 3245.

Wiyanto, W. (2019). Pelatihan Pembutan Nugget Jambu Mete bagi Ibu-Ibu PKK Desa Tegalmulyo Kecamatan Kragan Kabupaten Rembang. E-Dimas: Jurnal Pengabdian Kepada Masyarakat, 10(1), 11. https://doi.org/10.26877/e-dimas.v10i1.1844 


\section{Halaman Ini Dikosongkan}

